LA W RENCE LIVERMORE NATIONAL LABORATORY

\section{A Discussion of Reversible and Irreversible Sorption for $\mathrm{Sr}, \mathrm{Cs}$, $\mathrm{Np}$, and $\mathrm{Pu}$}

S. Carroll, R. Tinnacher, A. Kersting, M. Zavarin

May 7, 2010 
This document was prepared as an account of work sponsored by an agency of the United States government. Neither the United States government nor Lawrence Livermore National Security, LLC, nor any of their employees makes any warranty, expressed or implied, or assumes any legal liability or responsibility for the accuracy, completeness, or usefulness of any information, apparatus, product, or process disclosed, or represents that its use would not infringe privately owned rights. Reference herein to any specific commercial product, process, or service by trade name, trademark, manufacturer, or otherwise does not necessarily constitute or imply its endorsement, recommendation, or favoring by the United States government or Lawrence Livermore National Security, LLC. The views and opinions of authors expressed herein do not necessarily state or reflect those of the United States government or Lawrence Livermore National Security, LLC, and shall not be used for advertising or product endorsement purposes.

This work performed under the auspices of the U.S. Department of Energy by Lawrence Livermore National Laboratory under Contract DE-AC52-07NA27344. 


\title{
A Discussion of Reversible and Irreversible Sorption for Sr, Cs, Np, and Pu
}

\author{
By \\ Susan Carroll, Ruth Tinnacher, Annie Kersting, and Mavrik Zavarin \\ Lawrence Livermore National Laboratory
}

\subsection{Introduction}

Here we discuss the possibility that fission product and actinide sorption is reversible when thermodynamic and kinetic factors are accounted for in predictive models. We do this by reviewing the sorption behavior of $\mathrm{Sr}, \mathrm{Cs}, \mathrm{Np}$, and $\mathrm{Pu}$, and by reviewing our ability to model their sorption behavior. These elements were selected for review because short-lived $\mathrm{Sr}$ and $\mathrm{Cs}$ isotopes yield high dose and will be the likely constituents of reprocessed nuclear fuel. $\mathrm{Np}$ and $\mathrm{Pu}$ are important because they have long half-lives and may be transported in groundwater as dissolved $\mathrm{Np}$ species or Pu-containing colloidal solids. Here we highlight modeling approaches that have been used in key publications. No attempt is made to generate a comprehensive model for the radioactive elements listed above.

Ion sorption to mineral and amorphous solids has long been recognized as a process that controls the concentration of radioactive and trace elements in water. This process is particularly important for the transport of contaminants in the Earth's surface environment where sorption may retard transport of contaminants in groundwater by removing the contaminant to the non-mobile solid matrix. Efforts to describe sorption in complex geological settings typically uses a purely empirical approach in which distribution coefficients $\left(\mathrm{K}_{\mathrm{d}}\right)$ are a measure of distribution of an element between the solid and aqueous phases. Although this approach provides a direct measure of the ability of the solid matrix to sequester the contaminant from a specific solution, its empirical nature does not allow it to be applied outside of the specific parameters of the contaminated site. A broader approach is to measure thermodynamic parameters such as surface complexation constants, to describe sorption as a series of specific reactions between dissolved ions and surface sites. In principle, these thermodynamic data can be combined to build a model that represents the complex systems found in nature, especially when coupled with aqueous speciation, mineral solubility, and kinetic databases.

Complicating the accurate prediction of radionuclide fate and transport is the role of redox chemistry and reaction kinetics that control the long-term desorption of some radioactive elements from the solids surfaces back to the solution. For example, $\mathrm{Pu}$ sorption and desorption rates are controlled (or at least strongly influenced) by oxidation and reduction rates in solution and on the mineral surface to which it is sorbed (Powell et al., 2010). These complexities are not accounted for by current empirical treatments. 


\subsection{A predictive surface complexation model using $\mathrm{Sr}$}

Generally, alkaline earth elements such as $\mathrm{Sr}$ are believed to form outersphere complexes to mineral surfaces, rapidly reach equilibrium and are not limited by reaction kinetics. Here we illustrate a predictive surface complexation model for alkaline earth elements for a wide range of surface substrates by considering the role that strontium sorption may play for the safe disposal of radioactive waste. This is important because, an internally consistent surface complexation database for a wide range of ions and solids found in natural waters that capture the surface charge is still lacking (Ochs et al., 2006). Databases tend to adopt surface complexation models that account for surface charge if only one solid is available for uptake (Dzombak and Morrel, 1980) and non-electrostatic models that ignore surface charge if multiple solids are available for uptake (Davis et al., 1998, Zavarin and Burton, 2004a,b). Similar predictive models are needed for radioactive elements that appear to exhibit irreversible sorption as will be described for $\mathrm{Cs}, \mathrm{Np}$, and $\mathrm{Pu}$.

${ }^{90} \mathrm{Sr}$ is one of several fission products that are concentrated in nuclear weapon and energy reprocessing waste and may interact with several different oxides depending on the waste form and disposal environment. At the Hanford (Washington, USA) site, caustic liquid waste with high ${ }^{90} \mathrm{Sr}$ concentrations was disposed in tanks buried below the subsurface. Some of these tanks have leaked into the subsurface, where the migration of strontium is dependent on both its interaction with natural minerals and the reaction products formed from the interaction of the waste liquid with the subsurface fluvialglacial sedimentary deposits (Serne et al., 2004; Chorover et al., 2003; Choi et al., 2005). Future disposal of ${ }^{90} \mathrm{Sr}$ may include solid waste forms of cement, glass, or ceramics [Bao et al., 2005; Zhang et al., 2005; Grambow, 2006; Nyman and Hobbs, 2006 ]. The longterm disposal of ${ }^{90} \mathrm{Sr}$ depends not only on the stability of the waste form, but also on the sorption of strontium leached from the waste form to possible secondary phases, such as calcite, amorphous silica, iron hydroxides and rutile produced by the degradation of the waste form and corrosion of steel canisters containing the waste.

Sverjensky and colleagues have applied Born solvation and crystal-chemistry theory using a site-occupancy standard state to develop a predictive model for surface protonation, alkali, heavy metal, alkaline earth, and anion sorption (Sverjensky 1993, 1994, 2003, 2005, 2006; Sverjensky and Sahai, 1996, Sahai and Sverjensky, 1997a,b; Criscenti and Sverjensky, 1999, 2002). Carroll et al. (2008) augmented and re-calibrated Sverjenksy's model for the prediction of alkaline earth speciation sorbed on oxide surfaces by including the fitted strontium surface complexation reactions for goethite and amorphous silica. Fits to the sorption data using the following surface reactions on goethite and amorphous silica are shown in Figures 1 and 2:

$$
\begin{aligned}
& \left.2>\mathrm{SOH}+2>\mathrm{SO}^{-}+\mathrm{Sr}^{2+}+\mathrm{OH}^{-}=(>\mathrm{SOH})_{2}\left(>\mathrm{SO}^{-}\right)_{2} \mathrm{SrOH}^{+} \quad \text { (tet_SrOH }{ }^{+}\right) 1 \text {. } \\
& 2>\mathrm{SOH}+2>\mathrm{SO}^{-}+\mathrm{Sr}^{2+}=(>\mathrm{SOH})_{2}\left(>\mathrm{SO}^{-}\right)_{2} \mathrm{Sr}^{2+} \quad\left(\text { tet_ } \mathrm{Sr}^{2+}\right) \\
& >\mathrm{SO}^{-}+\mathrm{Sr}^{2+}+\mathrm{OH}^{-}=>\mathrm{SO}^{-} \mathrm{SrOH}^{+} \\
& >\mathrm{SOH}+\mathrm{Sr}^{2+}=>\mathrm{SOH} . . \mathrm{Sr}^{\overline{2}+}
\end{aligned}
$$



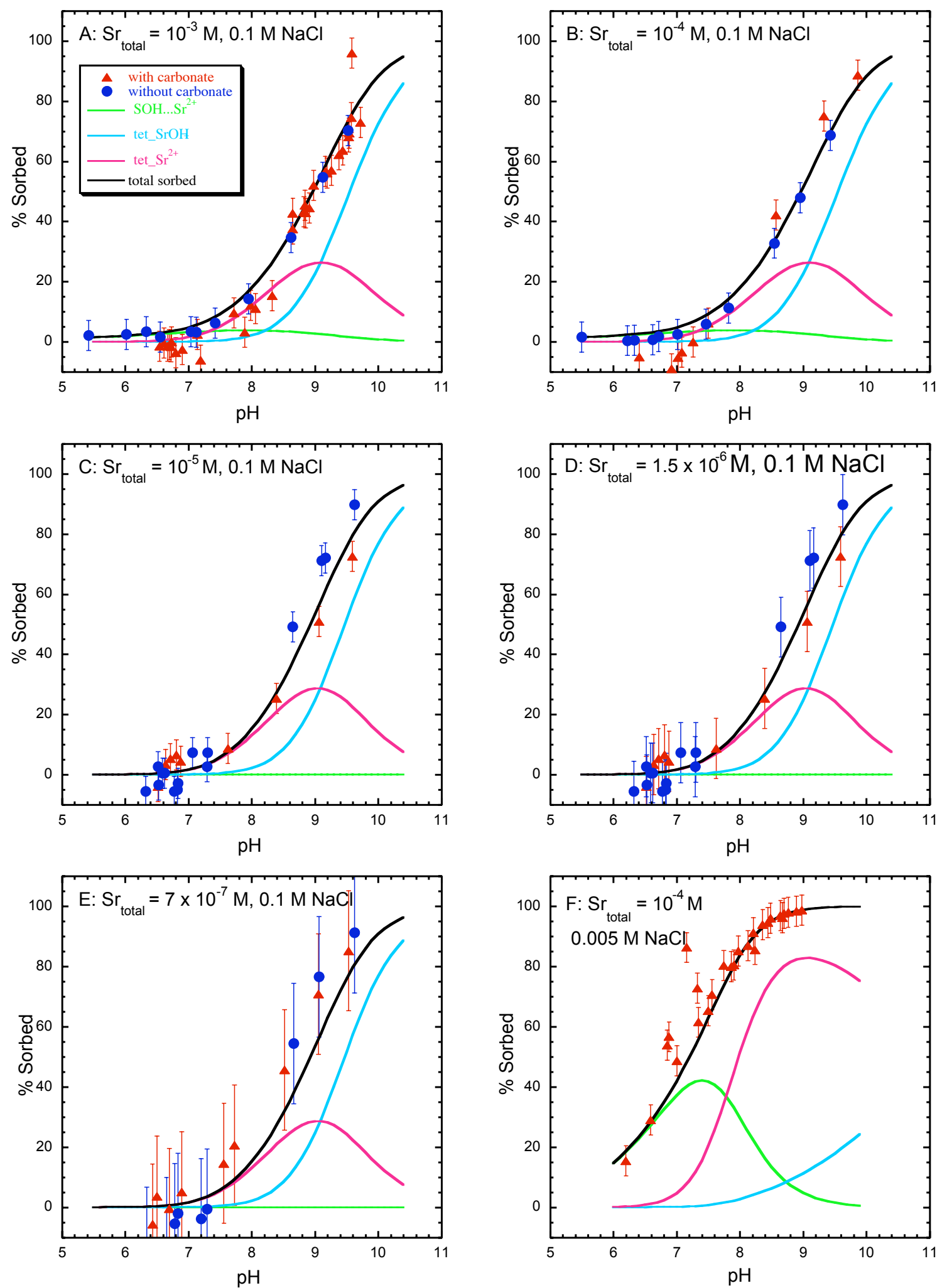

Figure 1. Comparison of experimental and model results for strontium sorption to amorphous silica in $7 \mathrm{x}$ $10^{-7}$ to $10^{-3} \mathrm{M} \mathrm{SrCl}_{2}$ and $0.1 \mathrm{M} \mathrm{NaCl}$ solutions with and without dissolved carbonate (A-E), and in $10^{-4} \mathrm{M}$ $\mathrm{SrCl}_{2}$ and $0.005 \mathrm{M} \mathrm{NaCl}$ solutions with dissolved carbonate $(\mathrm{F})$. Symbols are the experimental data and solid lines are fits to the data. 

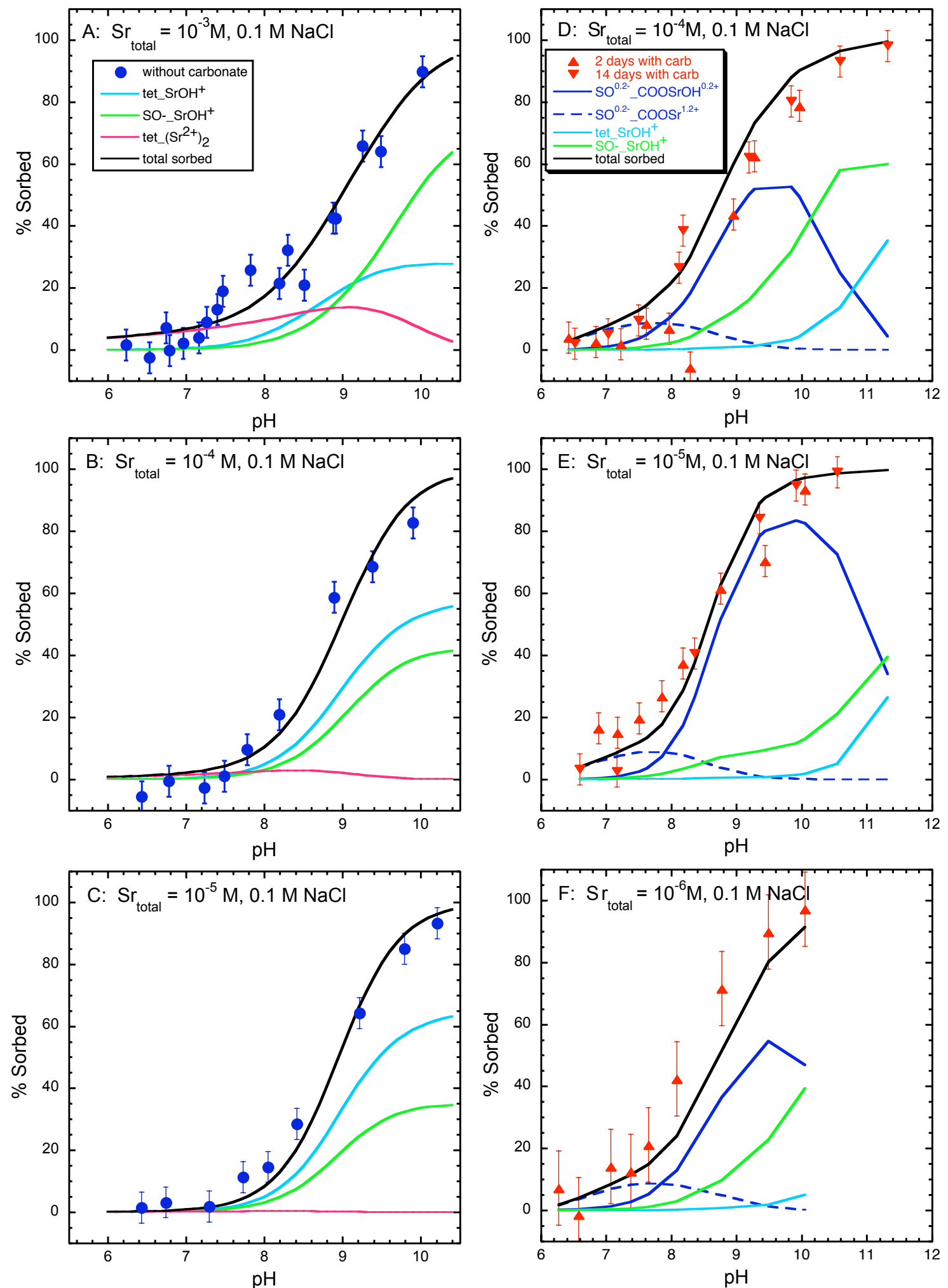

Figure 2. Comparison of experimental and model results for strontium sorption to goethite in $10^{-5}$ to $10^{-3}$ $\mathrm{M} \mathrm{SrCl}_{2}$ and $0.1 \mathrm{M} \mathrm{NaCl}$ solutions without dissolved carbonate (A-C) and in $10^{-6}$ to $10^{-4} \mathrm{M} \mathrm{SrCl}_{2}$ and $0.1 \mathrm{M}$ $\mathrm{NaCl}$ solutions with dissolved carbonate (D-F). Symbols are the experimental data and solid lines are fits to the data. 
Application of Born solvation and crystal-chemistry theory to metal sorption assumes that the standard Gibbs free energy of sorption $\left(\Delta \mathrm{G}_{\mathrm{r}, \mathrm{m}}^{\theta}\right)$ depends on contributions from ion solvation $\left(\Delta \mathrm{G}_{\mathrm{s}, \mathrm{m}}^{\theta}\right)$, electrostatic interactions between the sorbing ion and the surface sites $\left(\Delta \mathrm{G}_{\mathrm{ai}, \mathrm{m}}^{\theta}\right)$, and contributions specific to the sorbing ion $\left(\Delta \mathrm{G}_{\mathrm{ii}, \mathrm{m}}^{\theta}\right)$ :$$
\Delta \mathrm{G}_{\mathrm{r}, \mathrm{m}}^{\theta}=\Delta \mathrm{G}_{\mathrm{s}, \mathrm{m}}^{\theta}+\Delta \mathrm{G}_{\mathrm{ai}, \mathrm{m}}^{\theta}+\Delta \mathrm{G}_{\mathrm{ii}, \mathrm{m}}^{\theta}
$$

such that a given surface complexation equilibrium constant $\left(\log \mathrm{K}_{\mathrm{r}, \mathrm{m}}^{\theta}\right)$ can be expressed as:

$$
\log \mathrm{K}^{\theta}{ }_{\mathrm{r}, \mathrm{m}}=-\Delta \Omega_{\mathrm{r}, \mathrm{m}} / \mathrm{RT}^{*}\left(1 / \varepsilon_{\mathrm{s}}\right)-\mathrm{B}_{\mathrm{m}}\left(\mathrm{s} / \mathrm{r}_{\mathrm{m}}\right)+\log \mathrm{K}^{\prime \prime i, m}
$$

The first term on the right hand side of equation 5 accounts for ion solvation, where $\Delta \Omega_{\mathrm{r}, \mathrm{m}}$ is the Born solvation coefficient for the $\mathrm{r}^{\text {th }}$ reaction containing the metal $\mathrm{m}$ and $\varepsilon_{\mathrm{s}}$ is the dielectric constant for the solid. The second term accounts for the repulsive interaction between the sorbing ion and near surface species, where $\mathrm{s}$ is the Pauling's bond strength of the metal-oxygen bonds in the bulk mineral, $\mathrm{r}_{\mathrm{m}}$ is the distance the sorbing ion is repulsed by the underlying metal in the solid due to short-range electrostatic interactions, and $\mathrm{B}_{\mathrm{m}}$ is a constant characteristic of the surface reaction. The final term represents interactions intrinsic to the sorbing ion as well as solvation contributions from the interfacial dielectric constant and the electrostatic attractive interactions. Equation 5 can be reduced to:

$$
\log \mathrm{K}_{r, \mathrm{~m}}^{\theta}=-\Delta \Omega_{\mathrm{r}, \mathrm{m}} / \mathrm{RT}^{*}\left(1 / \varepsilon_{\mathrm{s}}\right)+\log \mathrm{K}^{\prime \prime}{ }_{\mathrm{ii}, \mathrm{m}}
$$

for a given surface reaction if the repulsive interactions in the electrostatic term are minimal. Linear regressions of $\log K_{r, m}^{\theta}$ versus $1 / \varepsilon_{\mathrm{s}}$ yield a slope equal to $-\Delta \Omega_{\mathrm{r}, \mathrm{m}} / \mathrm{RT}$ and a y-intercept equal to $\log \mathrm{K}^{\prime \prime i, m}\left(\right.$ or $\mathrm{B}_{\mathrm{m}}\left(\mathrm{s} / \mathrm{r}_{\mathrm{m}}\right)+\log \mathrm{K}{ }_{\mathrm{ii}, \mathrm{m}}$ if repulsion interactions are important). This regression serves as a fundamental calibration for the predictive model, because it allows the equilibrium constant for a given surface reaction to be estimated for solids of varying dielectric constants.

Figure 3 compares the difference between equilibrium constants for the formation of $(>\mathrm{SOH})_{2}\left(>\mathrm{SO}^{-}\right)_{2} \mathrm{MOH}^{+},(>\mathrm{SOH})_{2}\left(>\mathrm{SO}^{-}\right)_{2} \mathrm{M}^{2+}$ and $>\mathrm{SO}_{-}^{-} \mathrm{MOH}^{+}$fitted to sorption data and predicted directly by the regression of $\log \mathrm{K}_{\mathrm{r}, \mathrm{m}}^{\theta} \mathrm{Vs} 1 / \bar{\varepsilon}_{\mathrm{s}}$ (Equation 6 ) and by substitution of estimated values of $\Delta \Omega_{\mathrm{r}, \mathrm{m}}$ and $\log \mathrm{K}{ }^{\prime}{ }_{\mathrm{ii}, \mathrm{m}}$ into Equation 6. The overall alkaline earth model together with its predictive capability suggests that an additive approach can be used to describe sorption reactions in complex geochemical environments. The regression analysis suggests that alkaline earth sorption is largely a function of the solvation of the sorbing cation with minimal contributions between the sorbing cation and metals in the substrate as would be expected for outer-sphere sorption. Although the model can predict equilibrium constants for three non-carbonate surface reactions to within $\pm 0.7 \log \mathrm{K}$, this calibration remains fairly limited. 

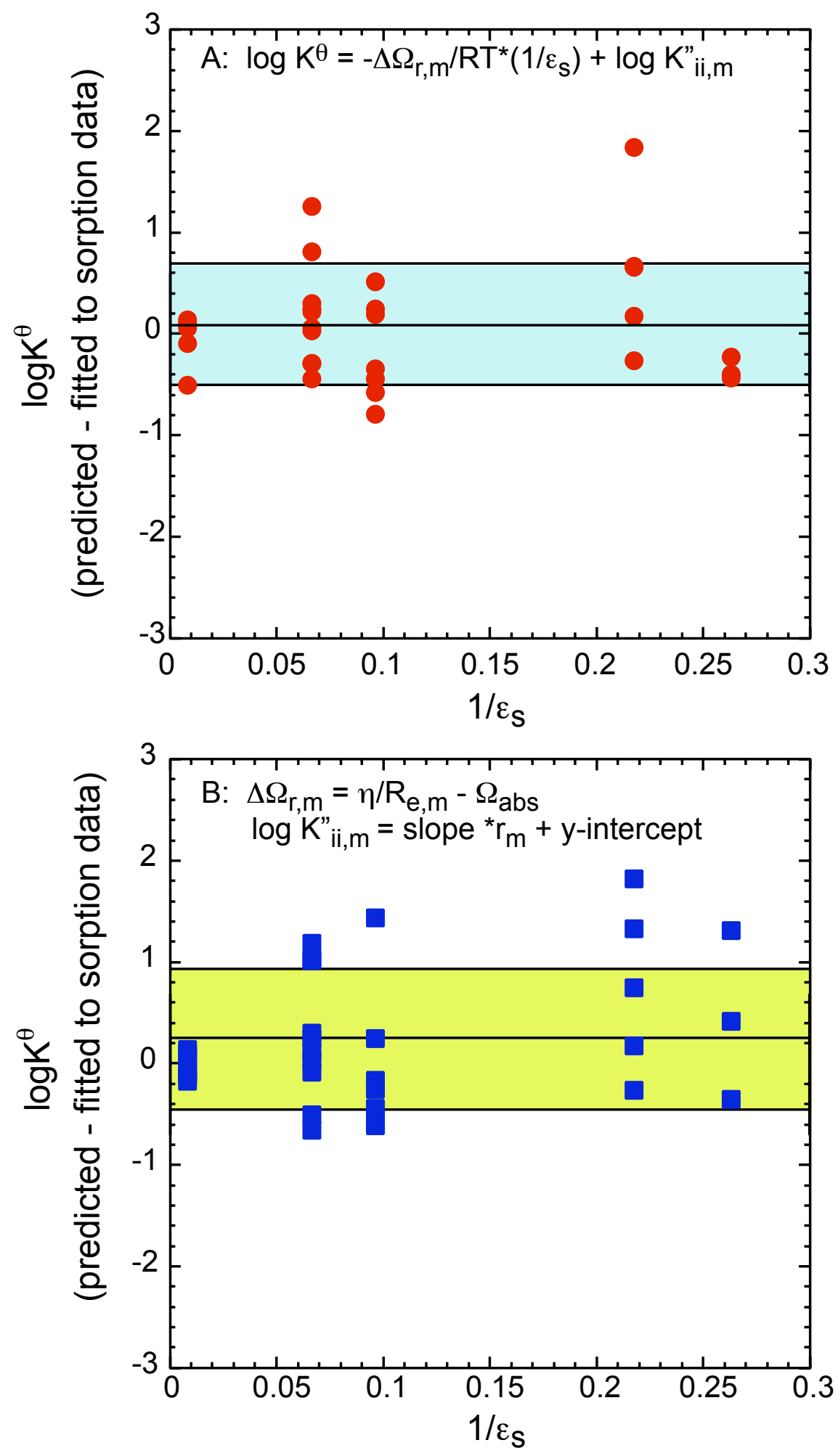

Figure 3. Comparison of $\log \mathrm{K}_{\mathrm{r}, \mathrm{m}}$ values fitted to sorption data and predicted from Born solvation and crystal chemistry theory using (A) regressions of $\log \mathrm{K}_{\mathrm{r}, \mathrm{m}}^{\theta}=-\Delta \Omega_{\mathrm{r}, \mathrm{m}} / \mathrm{RT}^{*}\left(1 / \varepsilon_{\mathrm{s}}\right)+\log \mathrm{K}^{\prime}{ }_{\mathrm{ii}, \mathrm{m}}$ (Equation 6) and (B) substitution of estimated $\Delta \Omega_{\mathrm{r}, \mathrm{m}}$ and $\log \mathrm{K}{ }_{\mathrm{ii}, \mathrm{m}}$ (see Carroll et al, 2008). Colored boxes correspond to standard deviation of 0.6 and $0.7 \log \mathrm{K}$ units in $\mathrm{A}$ and $\mathrm{B}$ respectively. 


\subsection{A multi-site model to describe reversible ${ }^{137} \mathrm{Cs}$ retardation exchange}

${ }^{137} \mathrm{Cs}$ is a by-product of processing of uranium fuels and a major component of nuclear wastes in the United States and other countries around the world. In a few cases, large amounts of ${ }^{137} \mathrm{Cs}$ have been released into the environment accidentally, as at Chernobyl in the former Soviet Union due to a reactor accident and at the Hanford site in the USA as a result of leaking of high level waste (HLW) storage tanks. It is well established that Cs is normally strongly sorbed by the clays and micas (Sawhney, 1970; Francis and Brinkley, 1976; Brouwer et al., 1983; Kemner et al., 1997; Poinssot et al., 1999; Zachara et al., 2002). Cs sorbs via ion exchange reactions to frayed edge sites (FES) on weathered micas and as hydrated cation on planar sites on expansible clays like smectite (Jackson, 1963; Rich and Black, 1964; Sawhney, 1970; Brouwer et al., 1983; Zachara et al., 2002).

Observations of the mobilization of Cs at Hanford led Zachara et al. (2002) and Steefel et al (2003) to conduct a systematic series of exchange experiments over a wide range of $\mathrm{Cs}^{+}, \mathrm{Na}^{+}, \mathrm{K}^{+}$, and $\mathrm{Ca}^{2+}$ concentrations using composite Hanford sediment from the SX tank farm. Their goal was to determine if a multi-site cation exchange model can be used to simulate Cs transport below the leaking Hanford tanks. The column experiments reviewed here provide a direct test of the reversibility of exchange by following the $\mathrm{Cs}^{+}$injection with elution of the column with concentrated $\mathrm{NaNO}_{3}$ or $\mathrm{NaOH}$ electrolyte alone (Steefel et al., 2003). Zachara et al. (2002) and Steefel et al (2003) found that multiple exchange sites with different affinities and abundances are needed to capture the large range in the distribution coefficient for Cs (Figure 4). Strong affinity sites are assumed to be associated with the frayed edges sites on weathered micas and weak sites are assumed to be associated with the surfaces of expansible layer silicates. Steefel et al (2003) formulated the multi-site cation exchange using the GainesThomas activity convention, which assumes a reaction stoichiometry of the following form (Appelo and Postma, 1993):

$$
C s^{+}+1 / m M X(i)_{m} \Leftrightarrow C s X(i)+1 / m M^{m+}
$$
where $\mathrm{M}$ is the competing cation $\left(\mathrm{Na}^{+}, \mathrm{K}^{+}, \mathrm{Ca}^{2+}\right), \mathrm{m}$ is its charge, and $\mathrm{X}(\mathrm{i})$ refers to the $\mathrm{i}^{\text {th }}$ type of exchange site. The exchange reactions can then be used to write a mass action equation for binary $\mathrm{Cs}-\mathrm{M}$ exchange:

$$
K_{M / C s}=\frac{\left[X(i)_{M}\right]^{1 / m}\left[C s^{+}\right]}{\left[X(i)_{C s}\right]\left[M^{m+}\right]^{1 / m}}
$$




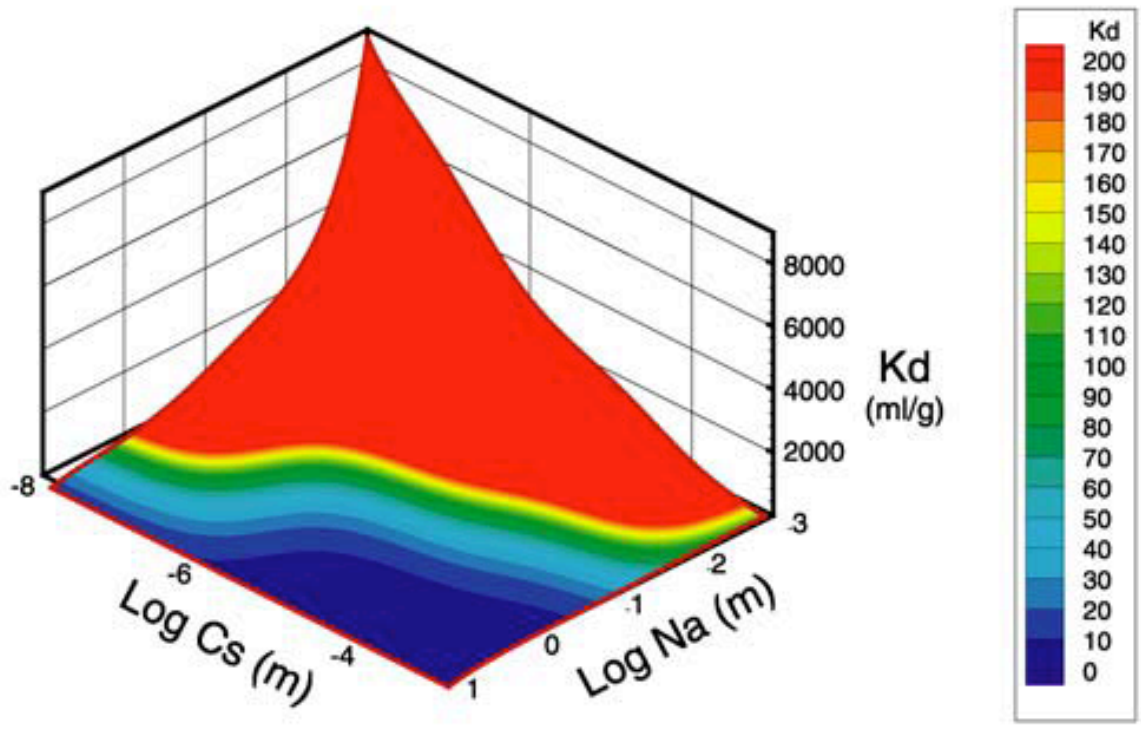

Figure 4: $\mathrm{Cs}$ distribution coefficient $\left(\mathrm{K}_{\mathrm{d}}\right)$ as a function of aqueous $\mathrm{Cs}$ and $\mathrm{Na}$ concentration for sediment from the SX tank farm, Hanford. Based on a global fit (this paper) of binary exchange data from Zachara et al. (2002). Full range of the $\mathrm{K}_{\mathrm{d}}$ (in units of $\mathrm{ml} / \mathrm{g}$ ) is 0 to 8000 as on surface plot-a narrower range of $0-200$ is used in color bar for illustration purposes only.

Assessing the reversibility of Cs exchange is crucial for predicting its mobility. Measurements of Cs desorption from contaminated S-SX sediments at Hanford (41-0939 and SX-108) suggest partial fixation of the sorbed Cs pool (McKinley et al., 2001). The reversibility of Cs exchange was examined by following the sorption stage with a desorption stage using an identical injection solution but without Cs (Figure 5). Column experiments conducted at Cs injection concentrations of $5 \times 10^{-6}$ and $5 \times 10^{-7} \mathrm{M}$, and $1 \mathrm{M}$ $\mathrm{NaNO}_{3}$ were specifically designed to test the reversibility of Cs exchange on FES, since under these conditions exchange on planar sites is minimal. These transport experiments show the strongest evidence for slow uptake of Cs into exchange sites, although it is not clear whether this is a kinetic effect related to slow diffusion into intralamellar sites in micas (e.g., Comans et al., 1991) or to multicomponent equilibrium effects (see Steefel et al 2003 for more details).

It appears that the slow desorption of Cs is primarily the result of the extremely high selectivity of the frayed edge sites for Cs vs. Na, based on the fact that the equilibrium model captures quite well the shape and actual concentrations of Cs during desorption. The slow desorption of $\mathrm{Cs}$, therefore, would appear to be an equilibrium effect and mostly reversible in the thermodynamic sense. Slow diffusion controlled release of $\mathrm{Cs}$, however, cannot be ruled out as a contributor to this effect, since it may be 
masked by the very long times required to desorb Cs even under equilibrium conditions. The equilibrium modeling predicts that about 300 pore volumes of $1 \mathrm{M} \mathrm{NaNO}_{3}$ is required to desorb $95 \%$ of the total Cs sorbed in the $5 \times 10^{-6} \mathrm{M}$ Cs experiment (Figure 5B). The difference between the $72 \%$ value actually measured and the $95 \%$ predicted by the equilibrium model is primarily the result of the extra mass of Cs sorbed on the Hanford sediment during the Cs uptake stage that was not captured by the modeling. It might be argued, therefore, that this $23 \%$ of the total Cs sorbed in this experiment is irreversibly sorbed. In experiments using higher injection concentrations of Cs and where exchange is therefore controlled primarily by sorption to planar sites, there is less evidence for irreversible Cs uptake. Presumably, any irreversible sorption on FES might not be apparent against the background of higher Cs input and output concentrations in these experiments. The Cs elution curves at higher Cs (Fig. 5 A \&D) show the closest agreement with the equilibrium exchange model, with only a minor discrepancy observed at Cs elution concentrations within $90 \%$ of the injection concentration. Mass balance calculations indicate that $95 \%$ of the originally exchanged $\mathrm{Cs}^{+}$was desorbed.
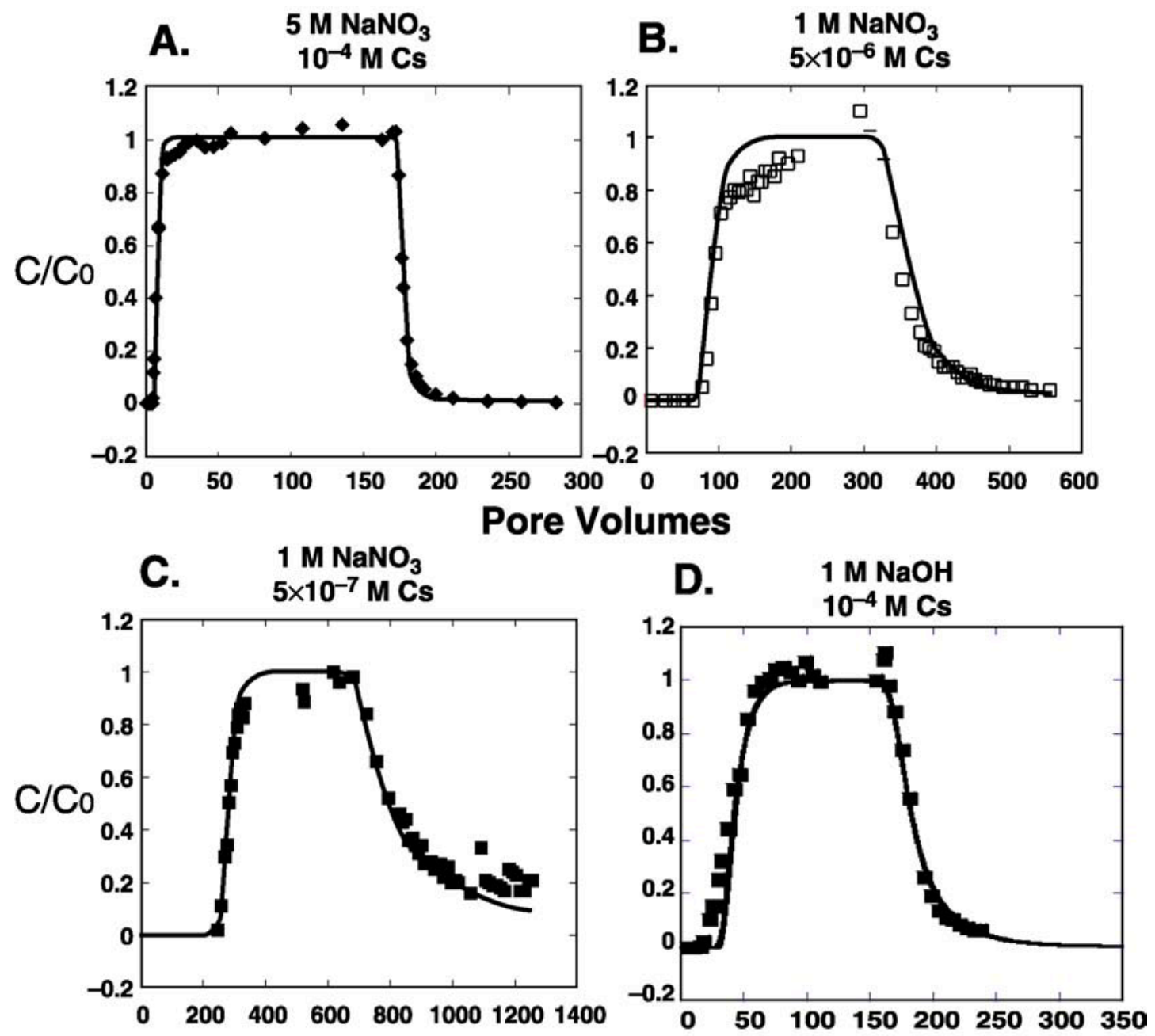

Pore Volumes

Figure 5. Reversibility of Cs exchange, with equilibrium reactive transport model results based on column weighted parameters to observed Cs elution. 


\subsection{The role desorption kinetics for Np on goethite}

$\mathrm{Np}$ desorption in the subsurface will be limited by the rate at which it desorbs from mineral surfaces, unlike the largely equilibrium behaviors of ${ }^{90} \mathrm{Sr}$ and ${ }^{137} \mathrm{Cs}$. Np desorption studies that assess the reversibility of $\mathrm{Np}$ sorption are limited to the numerous Np sorption studies (Keeney-Kennicutt and Morse, 1984; Combes et al., 1992; Girvin et al., 1991; Nakayama and Sakamoto, 1991; Tockiyama, et al., 1995; Kohler et al., 1999; Nakata et al., 2000). Most Np desorption data has been obtained through batch methods and system perturbation (e.g. changes in $\mathrm{pH}$ or addition of a complexant). Researchers frequently observed incomplete desorption of $\mathrm{Np}$, suggesting that a fraction of $\mathrm{Np}$ is "irreversibly" sorbed. Kenney-Kennicutt and Morse (1984) observed sorption hysteresis in batch experiments with goethite in seawater and distilled water. Nakata et al., (2000) observed greater than $50 \%$ desorption of $\mathrm{Np}$ from hematite and magnetite into a $1 \mathrm{M} \mathrm{KCl}$ solution. They also observed an increase in the fraction of unleachable $\mathrm{Np}$ over time, even after attempts to leach the $\mathrm{Np}$ from the surface with $0.1 \mathrm{M} \mathrm{K}_{2} \mathrm{C}_{2} \mathrm{O}_{4}$.

A recent experimental and modeling study of $\mathrm{Np}(\mathrm{V})$ sorption and desorption on goethite was performed by Powell et al (2010) and Tinnacher et al (2010) in a flow-cell system. Figure 6 shows the experimental $\mathrm{Np}$ data and fitted results of the adsorption and desorption parts of the experiment. An increase in $\mathrm{Np}$ effluent concentration follows each of the stopped-flow periods during the desorption part of the experiment. This indicates that the system did not achieve steady state within the average retention time during flow conditions (50 minutes) and that the Np desorption rate limits the overall reaction. Tinnacher et al (2010) were able to fit the Np sorption and desorption data with a kinetic model based on transition state theory (TST).

Transition state theory has been applied to the kinetics of mineral dissolution reactions (Lasaga 1998), but has not been used before to describe contaminant sorption/desorption kinetics onto minerals. Application of TST allows sorption and desorption rates to be linked to different thermodynamic driving forces and reaction pathways. According to transition state theory, each elementary rate constant $\left(k_{f}\right)$ is proportional to an exponential function of its associated activation energy $\left(E_{0}\right)$

$$
k_{f} \approx \exp \left(-\frac{E_{0}}{k_{B} T}\right)
$$

where $k_{B}$ represents the Boltzmann constant and $T$ temperature in $\mathrm{K}$. High activation energies are related to small rate constants and slow reaction rates, and vice versa. Based on the relationships between kinetics and thermodynamics, the ratio of the forward $\left(R_{f}\right)$ and reverse $\left(R_{r}\right)$ rates of an elementary reaction can be expressed as

$$
\frac{R_{f}}{R_{r}}=\frac{K_{e q}}{Q}=\exp \left(-\frac{\Delta G}{R T}\right)
$$

where $K_{e q}$ is the equilibrium constant, $\Delta G$ the free energy change (driving force) of the reaction, and $Q$ the reaction coefficient. For sorption systems, the reaction coefficient represents a conditional sorption constant describing ratios of sorbate and solution 
concentrations under non-equilibrium conditions. Thus the net rate of the reaction can be calculated as

$$
R_{n e t}=R_{f}-R_{r}=R_{f}\left(1-\exp \left(\frac{\Delta G}{R T}\right)\right)=R_{f}\left(1-\frac{Q}{K_{e q}}\right)
$$

if the reaction is limited by a single elementary reaction. If this is not the case, then equation 11 should be regarded as an empirical relationship describing the net kinetic rate of an overall reaction.

A more general form of the transition rate law formulation is

$$
R_{n e t}=R_{f}\left(1-\left(\frac{Q}{K_{e q}}\right)^{\psi}\right)
$$

where $\Psi$ should primarily be regarded as an empirical parameter for $\mathrm{Np}$ sorption.

In principal, transition state theory can be applied to any sorption model.

Tinnacher et al. (2010) found that a 2-site consecutive Freundlich model best fit the data (Figures 6 and 7) describing the change in aqueous Np concentration as:

$$
\frac{d C}{d t}=-k_{1} C^{n}\left(1-\left(\frac{Q_{1}}{K_{1}}\right)^{\psi_{1}}\right)
$$

and the change in the abundance of the transfer of $\mathrm{Np}$ from the second site to the first site, which represents a slow rate limiting sorption reaction:

$$
\frac{d S_{2}}{d t}=k_{2} S_{1}\left(1-\left(\frac{Q_{2}}{K_{2}}\right)^{\psi_{2}}\right)
$$

This model calculated activation energies as a function of the direction of the surface reaction by fitting the following parameters: $k_{l}, k_{-1}, n, \Psi_{1, a d}, \Psi_{1, d e}$ for site 1 and $k_{2}, k_{-2}$, $\Psi_{2, a d}, \Psi_{2, d e}$ for site 2 .

Overall their modeling results suggest that desorption kinetics are probably the most important factor controlling $\mathrm{Np}(\mathrm{V})$ desorption behavior under constant chemical conditions. Desorption rates are substantially slower than sorption kinetics and show a non-linear dependence on the driving force of the reaction. Aging processes take place after the initial sorption of $\mathrm{Np}(\mathrm{V})$ on the mineral surface. Hysteresis in terms of irreversible sorption behavior only plays a minor role if any. Desorption processes in this system are considered kinetically-limited but are not equivalent to irreversible sorption from a chemical perspective. These results are especially relevant for colloid-facilitated transport, since they imply that the reversibility of $\mathrm{Np}(\mathrm{V})$ sorption reactions is slow but possible. Slow desorption rates for contaminant desorption from bulk mineral phases may create 'continuous source terms' as low concentrations are continuously desorbed over long time-frames, leading to long tailings of contaminant plumes. 

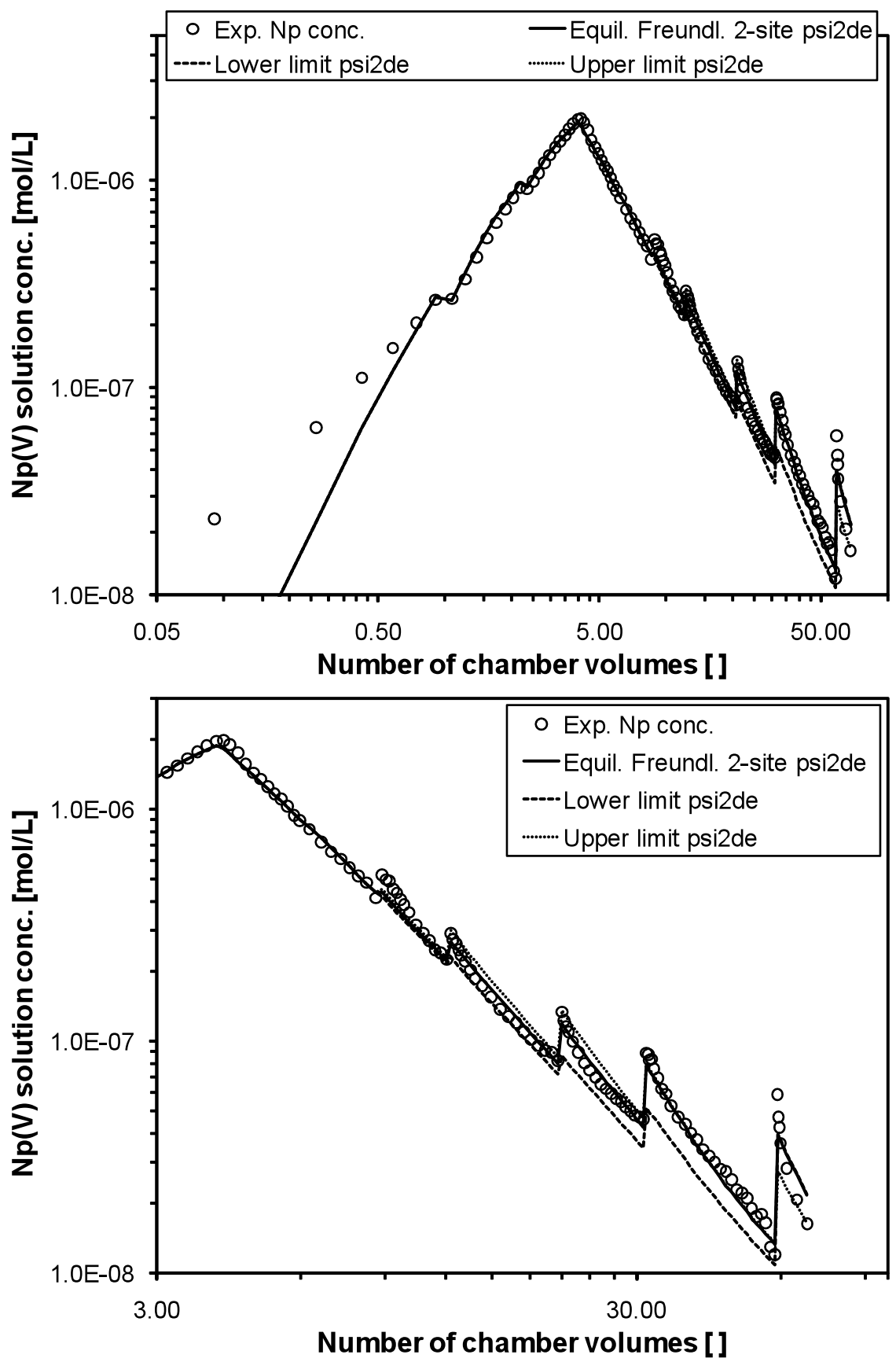

Figure 6. Best model fit with minimum number of fitting parameters: 2 -site model including an equilibrium Freundlich site (site 1), a consecutive first order site (site 2) and a fitting parameter $\Psi_{2, d e}$. Dashed lines represent calculated model outputs using the upper and lower limit values of $\Psi_{2, d e}(\mathrm{UL}=1.62$ $\left.\times 10^{-2}, \mathrm{LL}=3.75 \times 10^{-3}\right)$. 


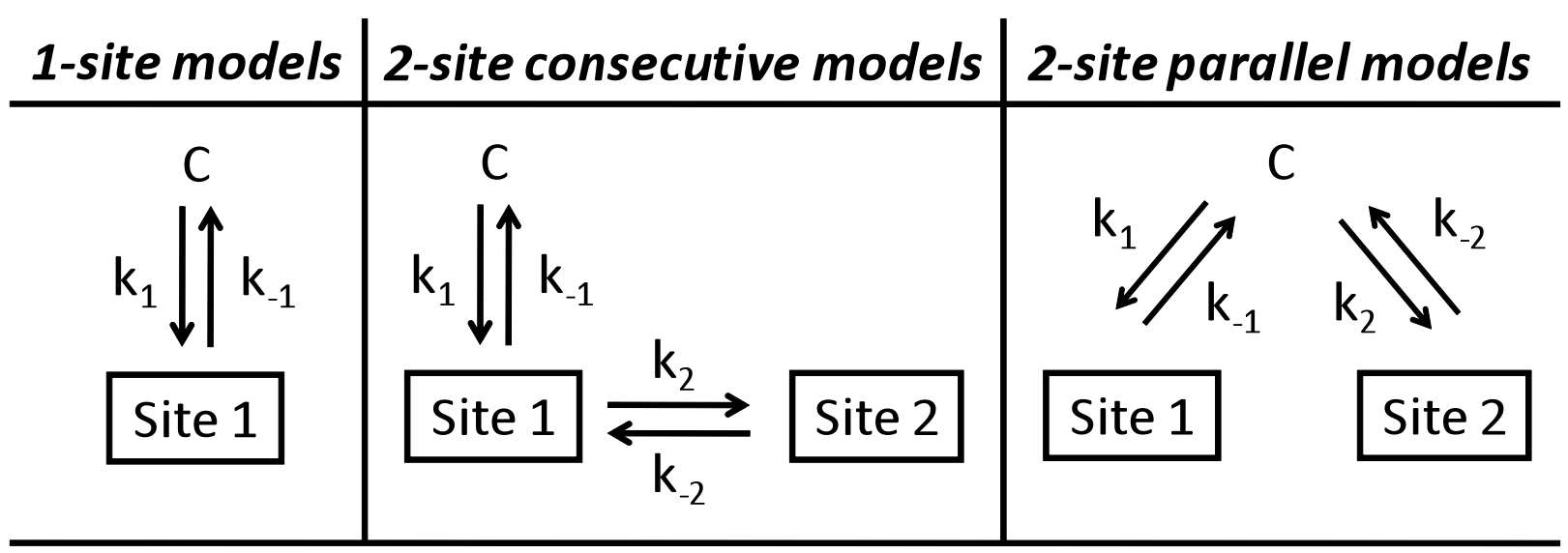

Figure 7. Examples of conceptual models used for the simulation of $\mathrm{Np}(\mathrm{V})$ sorption/desorption kinetics to goethite in 1-site and 2-site models. In all models, site 1 represents one of the following types of isothermbased sorption kinetics: first-order, Langmuir, Freundlich or empirical (Table 1). In 2-site consecutive models, site 2 represents reversible first-order sorption kinetics; in 2-site parallel models site 2 shows the same isotherm kinetics as site 1 .

\subsection{The role of redox state and desorption kinetics for $\mathrm{Pu}$ on goethite}

$\mathrm{Pu}$ exhibits the largest extent of so-called irreversible sorption of the radioactive elements reviewed here. The mobility of $\mathrm{Pu}$ is further complicated by surface-mediated reduction of $\mathrm{Pu}(\mathrm{V})$ to $\mathrm{Pu}(\mathrm{IV})$ resulting in drastically different sorption behavior. Reduction of $\mathrm{Pu}(\mathrm{V})$ to $\mathrm{Pu}(\mathrm{IV})$ promotes sorption due to the higher affinity of $\mathrm{Pu}(\mathrm{IV})$ for mineral surfaces, relative to $\mathrm{Pu}(\mathrm{V})$. Powell et al. (2004) determined an overall rate expression describing $\mathrm{Pu}(\mathrm{V})$ reduction by hematite and goethite as a function of solution pH. In continued studies, Powell et al., (2006) found that $\mathrm{Pu}(\mathrm{IV})$ was the dominant sorbed oxidation state for all synthetic minerals tested, even on oxidizing minerals such as pyrolysite $\left(\beta-\mathrm{MnO}_{2}\right)$.

The predominance of $\mathrm{Pu}(\mathrm{IV})$ on most mineral surfaces and $\mathrm{Pu}(\mathrm{V})$ in solution has confounded attempts to directly examine the desorption behavior of each $\mathrm{Pu}$ oxidation state. In batch experiments examining $\mathrm{Pu}$ desorption from hematite and goethite, less than $1 \%$ of the total sorbed $\mathrm{Pu}$ (added as either $\mathrm{Pu}(\mathrm{V})$ or $\mathrm{Pu}(\mathrm{IV})$ ) was desorbed in $\mathrm{J}-13$ well water and synthetic groundwater (Lu et al., 1999, 2003). In these studies the oxidation state of the desorbed $\mathrm{Pu}$ was not determined. However, the similarity in the desorbed fraction of each system suggests that an equilibrium distribution was reached independent of the initial $\mathrm{Pu}$ oxidation state. Incomplete leaching of $\mathrm{Pu}$ was observed after resuspending $\mathrm{Pu}$ equilibrated goethite in $0.6 \mathrm{M} \mathrm{HClO}_{4}$ (Kenney-Kennicutt and Morse, 1985). Furthermore, the fraction of leachable $\mathrm{Pu}$ decreased with increasing equilibration time from 1 hour to 30 days (Kenney-Kennicutt and Morse, 1985). This suggests that $\mathrm{Pu}$ became more strongly associated with the solids phase over time. This "aging effect" was also observed by Powell et al $(2004,2005)$ in similar experiments with goethite, hematite, and magnetite.

Tinnacher is currently applying the kinetic modeling approach that is described for $\mathrm{Np}$ above to $\mathrm{Pu}$ sorption/desorption kinetics on goethite. Here we comment on the experimental data of Powell et al. (2010). The high affinity of Pu uptake on goethite surfaces is shown in flow-through sorption/desorption experiments by the low ratio of $\mathrm{Pu}$ 
output to input concentrations during the sorption and the additional losses of aqueous $\mathrm{Pu}$ to the solid when flow was periodically stopped (Figure 8 and 9; Powell et al., 2010). Very low amounts of $\mathrm{Pu}$ desorb from goethite suggesting that kinetics play a key role for the partitioning of Pu back into solution (Figure 9). In is important to emphasize here, that sorption rates are non-zero. A steady decrease in the Pu concentration during active flow suggests there is a type of "aging" effect that caused desorption of Pu to become more unfavorable over the course of the experiment. Only $0.5 \%$ of the sorbed $\mathrm{Pu}$ was desorbed after passing 122 chamber volumes of $\mathrm{Pu}$-free solution through the flow cell. Powell et al (2010) hypothesize that the "aging effect" represents the repartitioning of sorbed $\mathrm{Pu}$ to more energetically favorable, strongly sorbing sites similar to the 2-site consecutive model that was developed for $\mathrm{Np}$ (Figure 7). The desorption rate was presumed to be limited by the oxidation of sorbed $\mathrm{Pu}(\mathrm{IV})$ to $\mathrm{Pu}(\mathrm{V})$ as a result of the previous surface mediated reduction of $\mathrm{Pu}(\mathrm{V})$ to $\mathrm{Pu}(\mathrm{IV})$ during adsorption.

$\mathrm{Pu}$ desorption processes are considered kinetically-limited but are not equivalent to irreversible sorption from a chemical perspective. These results are especially relevant for colloid-facilitated transport, since they imply that the reversibility of Pu sorption reactions may create 'continuous source terms' as low concentrations are continuously desorbed over long time-frames, leading to long tailings of contaminant plumes.

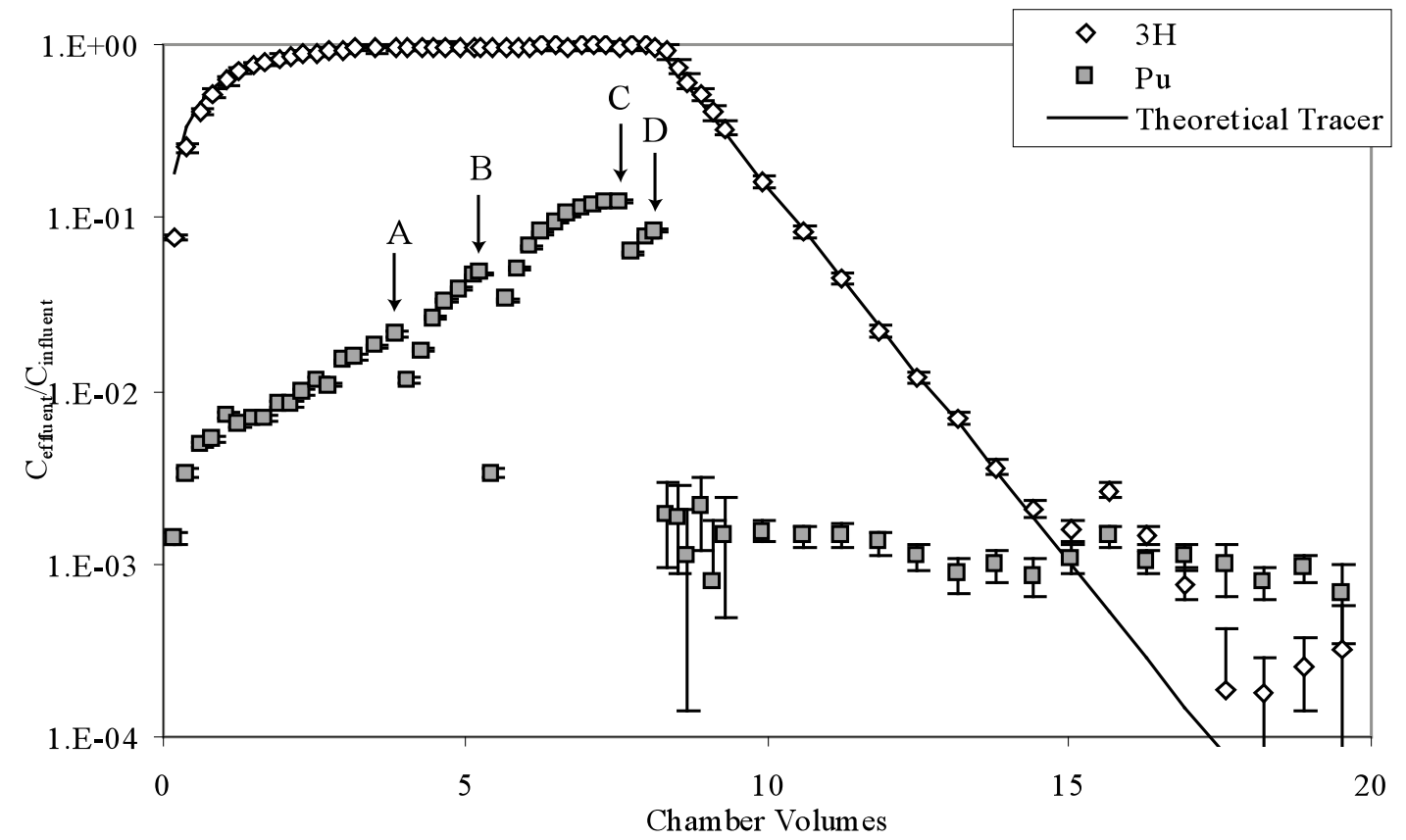

Figure 8: $\mathrm{Pu}$ and ${ }^{3} \mathrm{H}$ effluent profile from stirred flow-cell at $\mathrm{pH}$ 8. During the sorption step ( 0 to 8.3 chamber volumes) the background solution amended with $2.6 \mathrm{nM} \mathrm{Pu}(\mathrm{V})$ and $1000 \mathrm{cpm} \mathrm{mL}^{-1}{ }^{3} \mathrm{H}$ was pumped through the flow-cell. During the desorption step (started at point D above) only the background solution was pumped through the flow-cell. Arrows indicate periods of stopped flow for A) 1 hours, B) 18.5 hours, C) 1 hour, and D) 66 hours (also start of the desorption step). Solid line represents theoretical non-reactive tracer calculated using Equations 5 and 6 for the sorption and desorption steps, respectively. System parameters: Flow-rate $=12 \mathrm{~mL} \mathrm{hr}^{-1}$; Cell volume $=10 \mathrm{~mL}$; Background solution: $5 \mathrm{mM} \mathrm{NaCl}, 0.7$ $\mathrm{mM} \mathrm{NaHCO}, \mathrm{pH} 8$. 


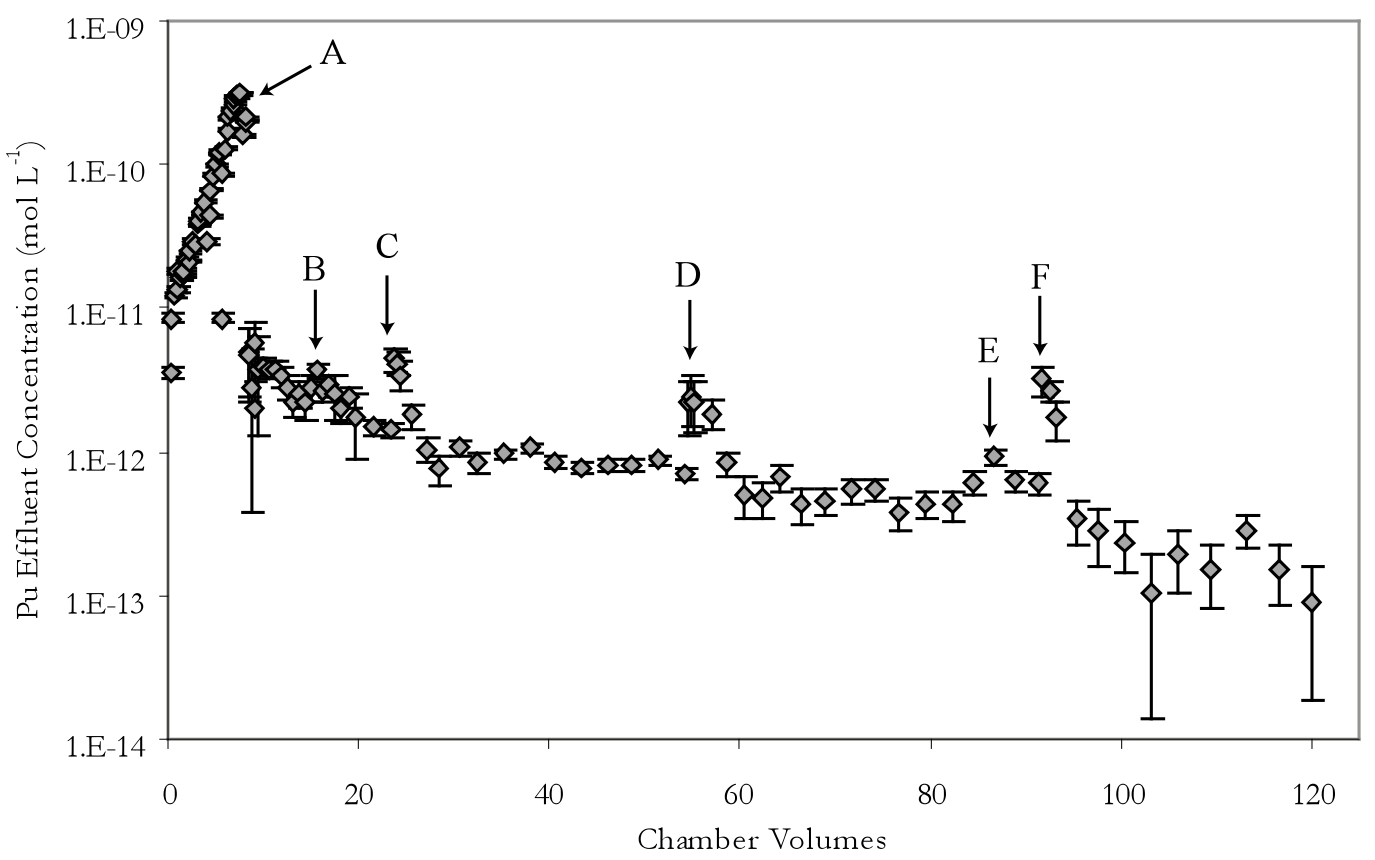

Figure 9: Pu aqueous concentration in the flow-cell effluent representing both sorption and desorption steps at $\mathrm{pH}$ 8. During the sorption step (0 to 8.3 chamber volumes) the background solution amended with $2.6 \mathrm{nM} \mathrm{Pu}(\mathrm{V})$ and $1000 \mathrm{cpm} \mathrm{mL}^{-13} \mathrm{H}$ was pumped through the flow-cell. During the desorption step (started at point $\mathrm{D}$ above) only the background solution was pumped through the flow-cell. Arrows indicate periods of stopped flow for A) start of desorption step, 66.0 hours, B) 16.3 hours, C) 42.0 hours, D) 96.0 hours, E) flow-rate decreased to $3 \mathrm{~mL} \mathrm{hr}^{-1}$, and F) 161.2 hours. System parameters: Flow-rate $=12 \mathrm{~mL} \mathrm{hr}$ ${ }^{1}$; Cell volume $=10 \mathrm{~mL}$; Background solution: $5 \mathrm{mM} \mathrm{NaCl}, 0.7 \mathrm{mM} \mathrm{NaHCO}_{3}, \mathrm{pH} 8$.

\subsection{Summary}

Review of key sorption/desorption studies show that $\mathrm{Sr}, \mathrm{Cs}, \mathrm{Np}$, and $\mathrm{Pu}$ cannot be described using only a single, linear distribution coefficient in fate and transport models. All four radioactive elements require multiple sites to capture their sorption behavior over a range of conditions. Equilibrium surface complexation or ion exchange reactions can adequately capture the uptake and release of $\mathrm{Sr}$ and $\mathrm{Cs}$ over a wide range of ionic strength, total element concentration, and solution $\mathrm{pH}$. Several elements exhibit aging effects where quantification of desorption kinetics are important. This is especially true for $\mathrm{Np}$ and $\mathrm{Pu}$ transport, but also true for Cs.

This report provides the background information needed to develop a research program for the robust risk assessment radioactive waste disposition in geologic environments. Challenges to state-of-the-art predictive modeling reside in quantification of sorption/desorption rates and identification of appropriate mechanistic modeling approaches. Temperature effects are a fundamental issue that is directly linked (via activation energy) to our understanding of sorption/desorption kinetics and our ability to predict actinide and trace element behavior under thermohydrologically complex conditions. 
Acknowledgements: The authors of this report would like to thank Louise Criscenti, Peggy

O'Day, Brian Powell, Sarah Roberts, Carl Steefel, and Pihong Zhoa as authors of the four main manuscripts reviewed in this report.

\section{REFERENCES}

Appelo, C.A.J., Postma, D. (1993) Geochemistry, Groundwater, and Pollution. A.A. Balkema, Rotterdam

Bao Y, Grutzeck MW, Jantzen CM: Preparation and properties of hydroceramic waste forms made with simulated Hanford low-activity waste, J. Am. Ceram. Soc. 2005, 88, 3287-3302.

Brouwer, E., Baeyens, B., Maes, A., Cremers, A. (1983) Cesium and rubidium ion equilibria in illite clay. Journal of Physical Chemistry 87, 1213- 1219.

Choi S, Amistadi MK, and Chorover J (2005) Clay mineral weathering and contaminant dynamics in a caustic aqueous system 1 . Wet chemistry and aging effects, Geochimica et Cosmochimica Acta, 69, 4425-4436.

Choi S, O'Day PA, Rivera NA, Mueller KT, Vairavamurthy MA, Seraphin S, Chorover J (2006) Strontium speciation during reaction of kaolinite with simulated tankwaste leachate: Bulk and microfocused EXAFS analysis. Environmental Science and Technology, 40, 2608-2614.

Chorover J, Choi S, Amistadi MK, Karthikeyan KG, Crosson G, Mueller KT (2003) Linking cesium and strontium uptake to kaolinite weathering in simulated tank waste leachate. Environmental Science and Technology, 37, 2200-2208.

Comans, R.N., Haller, J.M., De Preter, P. (1991) Sorption of cesium on illite: nonequilibrium behavior and reversibility. Geochimica et Cosmochimica Acta 55, $433-440$

Criscenti LJ, Sverjensky DA (1999) The role of electrolyte anions $\left(\mathrm{ClO}_{4}^{-}, \mathrm{NO}_{3}{ }^{-}\right.$, and $\left.\mathrm{Cl}^{-}\right)$ in divalent metal $\left(\mathrm{M}^{2+}\right)$ adsorption on oxide and hydroxide surfaces in salt solutions. American Journal of Science, 299, 828-899

Criscenti LJ, Sverjensky DA (2002) A single-site model for divalent transition and heavy metal adsorption over a range of metal concentrations. Journal of Colloid and Interface Science, 253, 329-352

Davis JA, Coston JA, Kent DB, Fuller CC (1998) Application of the surface complexation concept to complex mineral assemblages. Environmental Science and Technology, 32, 2820-2828

Dzombak DA, Morel FMM (1990) Surface Complexation Modeling: Hydrous Ferric Oxide. John Wiley and Sons

Francis, C.W., Brinkley, F.S. (1976) Preferential adsorption of 137Cs to micaceous minerals in contaminated freshwater sediment Nature 260, $511-513$

Grambow B (2006) Nuclear Waste Glasses - How durable? Elements, 2, 357-364.

Jackson, M.L. (1963) Interlaying of expansible layer silicates in soils by chemical weathering. Clays and Clay Minerals 11, 29- 46

Kemner, K.M., Hunter, D.B., Bertsch, P.M., Kirkland, J.P., Elam, W.T. (1997) Determination of the site-specific binding environments of surface sorbed cesium on clay minerals by Cs-EXAFS. Journal de Physique, IV France 7, 777- 779

Keeney-Kennicutt, W. L., Morse J. W. (1984). "The interaction of Np(V)O2+ with common mineral surfaces in dilute aqueous solutions and seawater." Marine Chemistry 15: 133-150 
Khasanova, A. B., Shcherhina, N.S., Kalmykov, S. N., Teterin, Yu A., Novikov, A. P. (2007) Sorption of $\mathrm{Np}(\mathrm{V}), \mathrm{Pu}(\mathrm{V})$ and $\mathrm{Pu}(\mathrm{IV})$ on Colloids of $\mathrm{Fe}(\mathrm{III})$ Oxides and Hydrous Oxides and $\mathrm{MnO}_{2}$ Radiochemistry 49(4), 419-425 (Originally published in Radiokhimiya, 2007, 49(4), 367-372

Lu, N., Cotter, C. R., Kitten, H. D., Bentley, J., Triay, I. R., (1999) Reversibility of sorption of plutonium-239 onto hematite and goethite colloids. Radiochim. Acta 83, 167-173.

Lu, N., Reimus, P. W., Parker, G. R., Conca, J. L., Triay, I. R. (2003) Sorption Kinetics and Impact of Temperature, Ionic Strength, and Colloid Concentration on the Adsorption of Plutonium-239 by Inorganic Colloids Radiochim. Acta 91, 713720.

McKinley, J.P., Serne, R.J., Zachara, J.M., Zeissler, C.J., Lindstrom, R.M. (2001) The distribution and retention of $137 \mathrm{Cs}$ in sediments beneath leaked waste at the Hanford site. Environmental Science and Technology 35, 3433-3441

Nyman M, Hobbs DT (2006) A family of peroxo-titantate materials tailored for optimal strontium and actinide sorption. Chem. Mater., 18, 6425-6435

Ochs M, Davis JA, Olin M, Payne TE, Tweed CJ, Askarieh MM, Altmann S (2006) Use of thermodynamic sorption models to derive radionuclide $K_{d}$ values for performance assessment: Selected results and recommendations of the NEA sorption project. Radiochimica Acta, 94, 799-785

Penrose, W. R., Metta, D. N., Hylko, J. M., Rinckel, L. A. (1987) Chemical Speciation of Plutonium in Natural Waters J. Environ. Radioactivity 5, 169-184

Poinssot, C., Baeyens, B., Bradbury, M.H. (1999) Experimental and modeling studies of cesium sorption on illite. Geochimica et Cosmochimica Acta, 63, 3217- 3227.

Powell, B. A., Duff, M. C., Kaplan, D. I., Bertsch, P. M., Coates, J. T., Eng, P., Fjeld, R. A., Hunter, D. B., Newville, M., Rivers, M. L., Serkiz, S. M., Sutton, S. R., Triay, I. R., Vaniman, D. T. (2006) Plutonium Oxidation and Subsequent Reduction by Mn(IV) Minerals in Yucca Mt. Tuff Environ. Sci. Tech. 40(11), 3508-3514.

Powell, B. A., R. A. Fjeld, D. I. Kaplan, J. T. Coates and S. M. Serkiz (2004). Pu(V)O$2(+)$ adsorption and reduction by synthetic magnetite (Fe3O4). Environmental Science \& Technology 38, 6016-6024

Powell, B. A., Fjeld, R. A., Kaplan, D. I., Coates, J. T., Serkiz, S. M. (2005) Pu(V)O ${ }_{2}^{+}$ Adsorption and Reduction on Synthetic Goethite $(\alpha-\mathrm{FeOOH})$ and Hematite $(\alpha-$ $\mathrm{Fe}_{2} \mathrm{O}_{3}$ ) Environ. Sci. Tech. 39(7), 2107-2114.

Powell, B. A., Kesting, A. B., Zavarin, M. (2010) Sorption and Desorption Rates of Plutonium on Goethite. To be submitted

Rich, C.I., Black, W.R. (1964) Potassium exchange as affected by cation size, pH, and mineral structure. Soil Science 97, 384- 390

Sahai N, Sverjensky DA (1997a) Evaluation of internally consistent parameters for the triple-layer model by the systematic analysis of oxide surface titration data. Geochimica et Cosmochimica Acta, 61, 2801-2826

Sahai N, Sverjensky DA (1997b) Solvation and electrostatic model for specific electrolyte adsorption. Geochimica et Cosmochimica Acta, 61, 2827-2848

Sanchez, A. L., Murray, J. W., Sibley, T. H. (1985) The Adsorption of Plutonium IV and V on Goethite Geochim. Cosmo. Acta 49, 2297-2307

Sawhney, B.L. (1970) Potassium and cesium ion selectivity in relation to clay mineral 
structure. Clays and Clay Minerals 18, 47-52.

Serne RJ, Bjornstad BN, Horton DG, Lanigan DC, Lindenmeier CW, Lindberg MJ, Clayton RE, LeGore VL, Geiszler KN, Baum SR, Valenta MM, Kutnyakov I. V, Vickerman TS, Orr RD, Brown CF (2004) Characterization of vadose zone sediments below the T Tank farm: Boreholes C4104, C4105, 299-W10-196 and RCRA borehole 299-W11-39. Pacific Northwest National Laboratory, PNNL14849

Steefel C. I., Carroll S. A., Zhao P., Roberts S. (2003) Cesium migration in Hanford sediment: A multi-site cation exchange model based on laboratory transport experiments. J. Contaminant Hydrology 67, 219-246

Sverjensky DA (1993) Physical surface-complexation models for sorption at the mineralwater interface. Nature, $364,776-780$

Sverjensky DA (1994) Zero-point-of-charge prediction from crystal chemistry and solvation theory. Geochimica et Cosmochimica Acta, 58, 3123-3129

Sverjensky DA (2001) Interpretation and prediction of triple-layer model capacitances and the structure of the oxide-electrolyte-water interface. Geochimica et Cosmochimica Acta, 65, 3643-3655

Sverjensky DA (2003) Standard states for the activities of mineral surface sites and species. Geochimica et Cosmochimica Acta, 67, 17-28

Sverjensky DA (2005) Prediction of surface charge on oxides in salt solutions: Revisions for 1:1 $\left(\mathrm{M}^{+} \mathrm{L}^{-}\right)$electrolytes. Geochimica et Cosmochimica Acta, 69, 225-257

Sverjensky DA (2006) Prediction of the speciation of alkaline earths adsorbed on mineral surfaces in salt solutions. Geochimica et Cosmochimica Acta, 70, 2427-2453

Sverjensky DA, Sahai N (1996) Theoretical prediction of single-site surface-protonation equilibrium constants for oxides and silicates in water. Geochimica et Cosmochimica Acta, 60, 3773-3797

Tinnacher R. M., Powell, B. A., Kersting, A. B., Zavarin, M. (2010) Simulation of aging, hysteresis and rate differences between sorption and desorption reactions in a neptunium(V)-goethite system. To be submitted to Geochimica et Cosmochimica Acta

Zachara, J.M., Smith, S.C., Liu, C., McKinley, J.P., Serne, R.J., Gassman, P.L. (2002) Sorption of $\mathrm{Cs}^{+}$to micaceous subsurface sediments from the Hanford site, USA. Geochimica et Cosmochimica Acta, 66, 193-211

Zavarin M, Bruton C (2004a) A non-electrostatic surface complexation approach to modeling radionuclide migration at the Nevada Test Site I. Iron hydroxides and calcite. Lawrence Livermore National Laboratory UCRL-TR-208673

Zavarin M, Bruton C (2004b) A non-electrostatic surface complexation approach to modeling radionuclide migration at the Nevada Test Site II. Aluminosilicates. Lawrence Livermore National Laboratory. UCRL-TR-208672

Zhang Z, Blackford MG, Lumpkin GR, Smith KL, Vance ER (2005) Aqueous dissolution of perovskite $\left(\mathrm{CaTiO}_{3}\right)$ : Effects of surface damage and $\left[\mathrm{Ca}^{2+}\right]$ in the leachant. $J$. Mater. Res., 20, 2462-2473 